\title{
FAKTOR-FAKTOR YANG MEMENGARUHI PEMBELIAN PRODUK MELALUI TV HOME SHOPPING
}

\section{FACTORS AFFECTING PRODUCT PURCHASES THROUGH TV HOME SHOPPING}

\section{Maria Tri Rahayu ${ }^{*}$, Budi Suharjo ${ }^{* *}$, dan Lilik Noor Yuliati***)}

*) PT Neohaus Indonesia

Jl. Prof. DR. Satrio Kav. 3-5, Ciputra World 1, Jakarta Selatan 12940

**) Departemen Matematika, Fakultas Matematika dan Ilmu Pengetahuan Alam, Institut Pertanian Bogor Jl. Meranti Kampus IPB, Dramaga, Bogor, Jawa Barat 16680

${ }^{* * *}$ Departemen Ilmu Keluarga dan Konsumen, Fakultas Ekologi Manusia, Institut Pertanian Bogor Gedung GMSK Lantai 2, Kampus IPB Dramaga Bogor 16680

\begin{abstract}
This research aimed to improve better understanding on consumer behavior of TV Home Shopping (THS) by identifying the behavior of consumers watching THS, analyzing the effect of THS on consumer interest in purchasing THS products on consumer groups who have needs and who do not, and giving recommendation on THS program development to increase sales. In this research, the data were taken in the form of surveys through direct interviews using questionnaire as the instrument tool. The research data were processed by PLS smart software. The results showed that the respondents' profiles as THS product buyers were dominated by women (63\%), adults (30-39 years old, 51\%), high education background (S1, 50\%), full-time workers $(56 \%)$, and middle to upper class communities (42\%). There were three major THS channels chosen by the respondents i.e. OShop (47\%), Lejel Home Shopping (37\%), and MNC Shop $(15 \%)$. The results of this research identified the primary reasons of purchasing products in THS i.e. product prices, appealing gifts, unique products, trending products, time saving, high quality products, needs for the products, lower prices, convenience by staying at home, and shopping for pleasure/gifts.
\end{abstract}

Keywords: commercial, TV Home Shopping, AIDA

\begin{abstract}
Abstrak: Penelitian ini bertujuan meningkatkan pemahaman yang lebih baik tentang perilaku konsumen TV Home Shopping (THS) dengan mengidentifikasi perilaku masyarakat dalam menonton THS, menganalisis pengaruh THS terhadap minat konsumen dalam membeli produk THS pada kelompok konsumen yang butuh dan belum butuh, dan memberikan rekomendasi pengembangan program THS untuk meningkatkan penjualan. Pada penelitian ini, data diperoleh dengan metode survei melalui wawancara langsung dengan menggunakan bantuan instrumen kuesioner. Data penelitian diolah dengan bantuan software smart PLS. Hasil olah data memperlihatkan profil responden pembeli produk THS dalam penelitian ini sebagian besar adalah wanita (63\%) berusia dewasa (30-39 thn, 51\%), memiliki pendidikan cukup tinggi (S1, $50 \%$ ), bekerja full time (56\%) dan berkelas menengah atas (42\%). Tiga channel THS pilihan utama responden adalah OShop (47\%), Lejel Home Shopping (37\%), dan MNC Shop (15\%). Hasil penelitian tentang prioritas alasan membeli produk berturut-turut adalah harga produk, hadiah yang menarik, produk unik, produk sedang trend, hemat waktu, produk berkualitas, produk dibutuhkan, harga lebih murah, tidak perlu ketoko, beli untuk kesenangan/hadiah.
\end{abstract}

Kata kunci: Iklan, TV Home Shopping, AIDA

\footnotetext{
${ }^{1}$ Alamat Korespondensi:

Email: marianugroho88@gmail.com
} 


\section{PENDAHULUAN}

Seiring dengan perkembangan teknologi satelit yang sangat cepat dalam beberapa dekade terakhir, konsumen dihadapkan dengan berbagai kemudahan termasuk diantaranya kemudahan berbelanja. Selain dipusat perbelanjaan atau toko, konsumen masa kini bisa melakukan aktivitas belanja dengan tetap berada di rumah atau lebih dikenal dengan istilah home shopping. Aktivitas home shopping dilakukan, antara lain melalui media stasiun TV yang menawarkan berbagai kebutuhan konsumen.

Penjualan melalui TV Home Shopping (THS), termasuk dalam kategori t-commerse. Cara berbelanja melalui THS ini sering disebut sebagai salah satu revolusi cara belanja dari konvensional menjadi nonstore retail (Wood, 2015). Diduga revolusi belanja nonstore retail akan meningkat sebagai respon dari perubahan gaya hidup konsumen yang menginginkan kemudahan dan pelayanan yang lebih (Shaffer dan Easterling, 2000). Program THS dinilai lebih mudah dan praktis (tanpa perlu keluar rumah) dibanding dengan belanja di toko konvensional. Konsumen cukup melihat iklan produk atau jasa di layar televisi dan pemesanan dilakukan melalui call center yang tertera pada layar TV. Cara pembayaran dibuat memudahkan konsumen, dengan alternatif transfer, kartu kredit, atau pembayaran ditempat (COD). Dalam waktu singkat, petugas pengiriman akan menyerahkan barang pesanan ke alamat konsumen (Intarto, 2014). Cara berbelanja ini memberikan pengalaman baru bagi konsumen, karena menghemat waktu, biaya dan tenaga (Chen dan Tsai, 2008) dan Perilaku belanja konsumen semakin berubah, dari sekedar mencari harga murah, menjadi faktor kenyamanan belanja (Lee et al. 2012).

Ditinjau dari sisi sebuah perusahaan TV, sebuah program THS selain mengisi waktu tayang, juga merupakan sebuah konsep bisnis baru yang dapat menjadi sumber penghasilan baru bagi perusahaan. Melalui program THS, perusahaan TV bertindak sebagai retailer dan penonton program menjadi pembelinya. Dalam perkembangannya, sebuah program THS selain diharapkan menjadi sarana penjualan, juga diharapkan dapat meningkatkan nilai sebuah merek (Intarto, 2014).

Perkembangan THS di Indonesia, pertama kali diperkenalkan oleh DRTV pada tahun 2001. Perkembangan yang pesat terjadi pada sekitar tahun
2009 saat MNC Group masuk THS dengan MNC Shop dan Emtek Group dengan OShop. Meskipun tergolong bisnis baru, pertumbuhan penjualan THS di MNC TV cukup pesat. pada 2013 naik 419\% menjadi 262 milyar. Seperti juga di negara lain, THS merupakan salah satu kategori nonstore retail yang memiliki pertumbuhan sangat cepat selain e-commerce. THS diharapkan mampu merubah gaya belanja individu dan menciptakan peluang bisnis baru bagi layanan operator TV (Lin, 2010) dimana THS bertindak sebagai retailer (Ha dan Chan, 2001). Sampai saat ini, iklan produk melalui Televisi masih dianggap cukup efektif, karena memiliki beberapa elemen kekuatan sekaligus yaitu audio, visual dan gerak untuk mengkomunikasikan produk. Dari hasil riset di 10 kota besar di Indonesia yaitu Jakarta dan Bodetabek, Surabaya, Bandung, Semarang, Yogyakarta, Medan, Palembang, Denpasar, Makassar dan Banjarmasi, diketahui penetrasi televisi mencapai hingga $95 \%$, berarti mayoritas masyarakat Indonesia menggunakan media televisi setiap hari (Nielsen, 2014; Intarto, 2014). Dengan penetrasi yang tinggi, maka di Indonesia THS juga memiliki peluang cukup baik dalam penjualan produk.

Sebuah iklan di THS dapat memengaruhi perilaku dan persepsi belanja masyarakat yang menonton, khususnya perilaku konsumsi masyarakat (Lin, 2010). Perubahan perilaku konsumsi yang dapat disebabkan dari menonton iklan di TV, antara lain karena masyarakat memiliki informasi terhadap suatu barang ataupun jasa yang diiklankan. Mereka menjadi dapat memilih hal-hal apa saja yang dapat dikonsumsi untuk dapat memenuhi kebutuhan dirinya (Sumarwan, 2011). Tsai et al. (2011) menyatakan bahwa semakin banyak paparan iklan THS kepada konsumen, akan meningkatkan pengaruh kepada pembelian produk THS. Sebuah program THS yang baik adalah program yang mampu menarik perhatian, mendapatkan dan mendorong minat, membangkitkan keinginan, dan menghasilkan tindakan pembelian. Keberhasilan dan kegagalan program THS bergantung kepada seberapa baik iklan itu mampu berkomunikasi dengan konsumen.

Salah satu masalah yang dihadapi oleh perusahaan THS adalah biaya yang cukup mahal untuk menutup biaya produksi iklan dan sewa frekuensi. Apabila suatu program efektif dan tepat sasaran, maka angka penjualan akan meningkat dan memberikan keuntungan bagi perusahaan. Sebaliknya, bila program tidak tepat, maka akan merugikan perusahaan THS. Hingga saat ini, penjualan THS di Indonesia masih belum sesuai 
harapan. Diduga penjualan THS di Indonesia saat ini masih sekitar US\$ 2 milyar.

Penelitian mengenai peran iklan terhadap keputusan pembelian konsumen sudah cukup banyak dilakukan di berbagai industri di Indonesia. Namun demikian, penelitian tersebut belum banyak dilakukan untuk industri THS di Indonesia. Salah satu cara yang dapat dilakukan untuk mempempelajari respon konsumen terhadap program THS adalah dengan model respon AIDA. Model AIDA ini menggambarkan sebuah tahapan proses keputusan konsumen menuju pembelian, yaitu Awareness (Kesadaran), Interest (ketertarikan), Desire (Keinginan), dan Action (Tindakan). Dengan pemahaman yang tepat dapat menghasilkan program pemasaran produk THS yang lebih terencana, efisien, efektif dan tepat sasaran.

Tujuan dari penelitian ini adalah mengidentifikasi perilaku konsumen dalam menonton THS; menganalisis pengaruh THS terhadap minat konsumen dalam membeli produk THS; menghitung CRI akibat paparan THS; dan memberikan rekomendasi pengembangan program THS untuk meningkatkan penjualan.

\section{METODE}

Penelitian dilaksanakan di Jakarta, Pengambilan data penelitian dilaksanakan pada bulan Juni - September 2016 di arena Pekan Raja Jakarta Kemayoran. Pengambilan sampel menggunakan non probability sampling, dimana semua anggota populasi tidak memiliki peluang yang sama untuk dijadikan sebagai unit contoh (Suharjo, 2005). Teknik pengambilan sampel tak berpeluang yang digunakan adalah Convenience Sampling Method (metode sampel kemudahan). Data dikumpulkan melalui metode survei dengan cara wawancara langsung menggunakan bantuan instrumen kuisioner. Pemberian dan pengisian kuisioner dilakukan pada 105 responden yang sudah pernah membeli produk THS dalam kurun waktu 1 tahun terakhir. Data dianalisis dengan menggunakan analisis deskriptif, Thurston dan Smart PLS. Penilaian responden menggunakan skala Likert 1 sampai dengan 5 dengan Sangat Setuju (SS) merupakan bobot 5; Setuju (S) merupakan bobot 4; Netral (N) merupakan bobot 3; Tidak Setuju (TS) merupakan bobot 2; Sangat Tidak Setuju (STS) merupakan bobot 1 .
Model penelitian ini dapat dilihat pada Gambar 1 . Selanjutnya, variabel penelitian yang digunakan pada Tabel 1. Adapun hipotesis penelitian ini sebagai berikut:

H1 : Iklan memengaruhi Awareness terhadap produk THS

H2 : Iklan memengaruhi Interest terhadap produk THS

H3 : Iklan memengaruhi Desire terhadap produk THS

H4 : Iklan memengaruhi Action terhadap produk THS

H5 : Awareness meningkatkan Interest

H6 : Interest meningkatkan Desire

H7 : Desire meningkatkan Action

\section{HASIL}

\section{Profil Responden}

Profil responden merupakan karakter responden yang dilihat dari aspek demografi konsumen seperti usia, jenis kelamin, status pernikahan, jenis pekerjaan, pengeluaran per bulan, Melalui analisis demografi responden, akan didapatkan informasi mengenai kelompok demografi yang menjadi mayoritas dalam setiap kriterianya.

Jumlah responden yang terlibat dalam penelitian ini berjumlah 105 orang konsumen yang terbagi ke dalam dua kelompok responden yang memiliki kebutuhan, yaitu butuh $21 \%$ dan belum butuh $79 \%$. Seluruh responden tersebut pernah melakukan pembelian produk THS dalam kurun waktu 1 tahun dan tinggal di DKI Jakarta. Profil responden selengkapnya pada Tabel 2.

Hasil survei diketahui bahwa komposisi jenis kelamin didominasi oleh responden wanita. Jumlah responden wanita lebih dominan dalam hal pembelian produk dibandingkan pria. Pada penelitian ini, responden terbagi ke dalam empat rentang usia, 20-29 tahun, 30-39 tahun, 40-49 tahun, dan lebih dari 50 tahun. Berdasarkan hasil penelitian, jumlah responden yang paling dominan pada penelitian ini berasal dari golongan usia 30-39 tahun sebesar 51\%. Prosentase responden yang paling sedikit adalah kelompok usia usia $>50$ tahun sebesar 5\%. Dominasi responden usia 30-39 tahun menunjukkan konsumen pada usia ini umumnya sudah mapan dalam keluarga dan karir, dan memiliki 
penghasilan cukup untuk membeli produk sekunder. Hasil penelitian menunjukkan bahwa mayoritas responden berstatus menikah sebesar $89 \%$, sedangkan yang belum menikah adalah sebesar $11 \%$. Kondisi ini dapat dikaitkan dengan rentang usia responden yang didominasi oleh dua kelompok usia 30-39 tahun dan 40-49 tahun, kelompok yang pada umumnya sudah berstatus menikah sehingga dari berbagai kategori produkyang dipasarkan oleh perusahaan THS, mayoritas responden membeli produk untuk kebutuhan keluarga. Pada penelitian ini mayoritas responden adalah dengan tingkat pendidikan S1 sebesar 50\%, SMA 37\%, S2 $13 \%$. Profesi atau pekerjaan dapat menggambarkan status sosial seseorang, memengaruhi perilaku orang tersebut dalam membeli atau menggunakan suatu produk. Status sosial tersebut secara tidak langsung menggambarkan perbedaan gaya hidup, pendapatan, dan nilai-nilai yang dianut (Sumarwan, 2011). Hasil olah data menunjukkan bahwa responden yang bekerja sebagai pegawai swasta memiliki persentase terbesar, yakni 56\%. Tingkat pengeluaran akan menentukan daya beli seseorang dan selanjutnya akan memengaruhi pola konsumsinya. Hasil penelitian menunjukkan bahwa sebagian besar responden memiliki tingkat pengeluaran lebih dari Rp7.500.000 (42\%) dan persentase paling kecil memiliki tingkat pengeluaran kurang dari Rp4.500.000 sebesar 22\%.

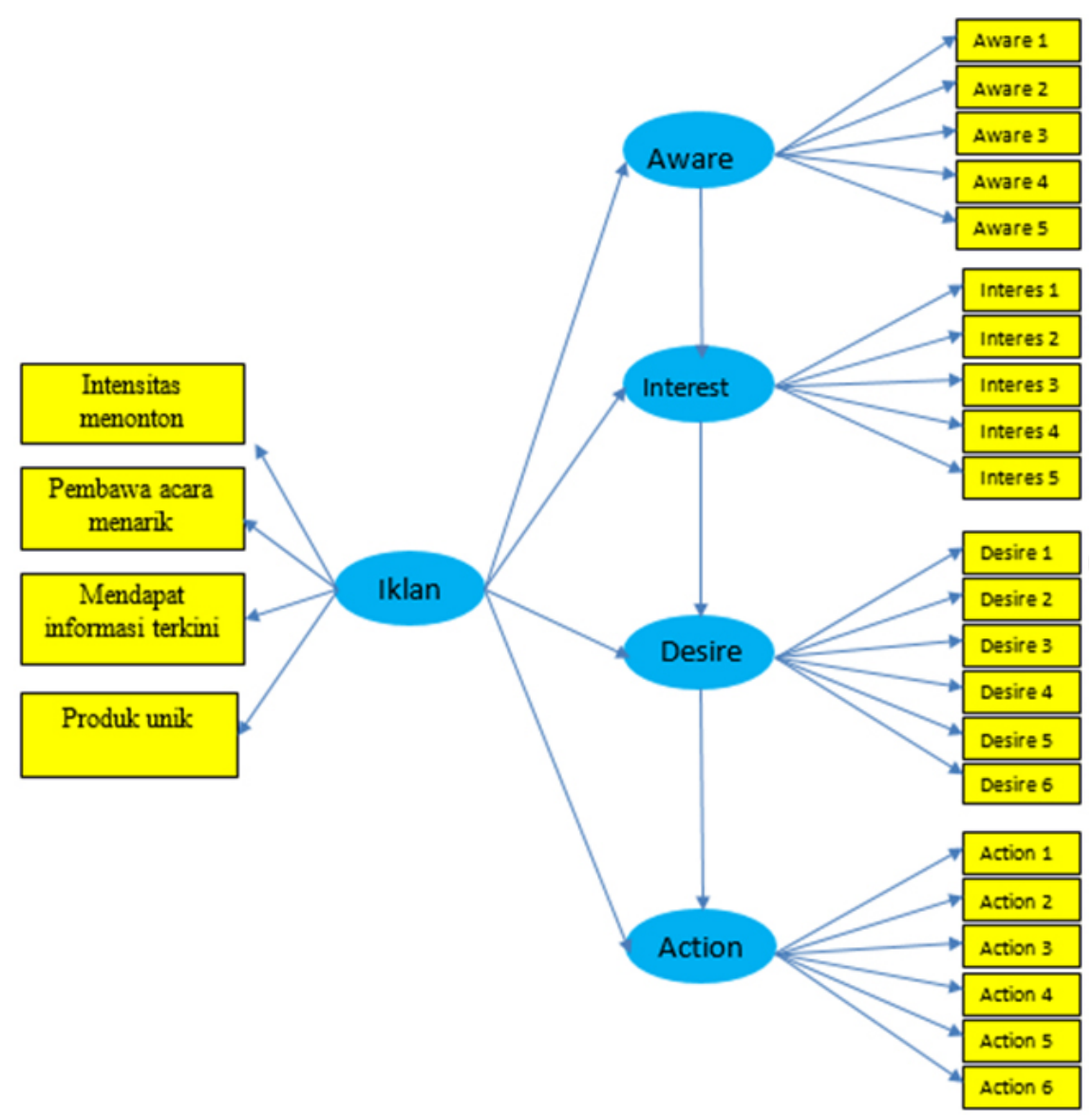

Gambar 1. Model konseptual penelitian

Tabel 1. Variabel penelitian

\begin{tabular}{lllc}
\hline Variabel eksogen & Definisi & Indikator & Skala pengukuran \\
\hline Iklan & Tindakan atau aktivitas menonton iklan & Intensitas Menonton (Iklan 1) & Ordinal \\
& & Pembawa acara menarik (Iklan 2) & Ordinal \\
& & Mendapat info terkini (Iklan 3) & Ordinal \\
\multirow{4}{*}{$\begin{array}{l}\text { Respon } \\
\text { menonton iklan }\end{array}$} & Produk unik (Iklan 4) & Ordinal \\
& Tujuan iklan adalah mendapatkan perhatian & Attention & Ordinal \\
& (attention), menarik minat (interest), & Interest & Ordinal \\
& menimbulkan keinginan (desire), dan & Desire & Ordinal \\
& merangsang konsumen untuk membeli & Action & Ordinal \\
& (action).Skala pengukuran menggunakan & & \\
\hline
\end{tabular}


Perilaku Menonton dan Persepsi terhadap Iklan THS

Perilaku menonton THS sangat penting diketahui oleh perusahaan THS, Karena akan menentukan efektifitas tujuan tayangan THS. Semakin sering dan semakin lama konsumen menonton THS, maka semakin positif persepsi konsumen terhadap produk dan perilaku pembelian (Lee, 2008). Hasil penelitian terhadap perilaku dan persepsi menonton THS disajikan pada Tabel 3.

Hasil penelitian menunjukkan bahwa tiga siaran THS yang paling banyak ditonton oleh responden adalah Oshop 47\%, Lejel Home Shopping 37\%, MNC 15\%. Dari hasil penelitian, mayoritas responden menonton THS diwaktu yang tidak tentu sebesar $70,5 \%$, menonton pada jam 12-15 siang 9,1\%, dan $18,4 \%$ menonton di waktu pagi dan malam. Sebagian besar responden menyatakan tidak ada hari khusus menonton THS, atau reponden tidak tentu dalam hari menonton.

Tabel 2. Profil Responden

\begin{tabular}{|c|c|c|}
\hline Atribut & $\mathrm{n}$ & $\%$ \\
\hline \multicolumn{3}{|l|}{ Jenis Kelamin } \\
\hline Laki-Laki & 36 & 37 \\
\hline Perempuan & 69 & 63 \\
\hline \multicolumn{3}{|l|}{ Usia Responden } \\
\hline $20-29$ & 11 & 11 \\
\hline $30-39$ & 54 & 51 \\
\hline $40-49$ & 35 & 33 \\
\hline $50<$ & 5 & 5 \\
\hline \multicolumn{3}{|l|}{ Status Pernikahan } \\
\hline Lajang & 12 & 11 \\
\hline Menikah & 93 & 89 \\
\hline \multicolumn{3}{|l|}{ Tingkat Pendidikan } \\
\hline SMA & 39 & 37 \\
\hline $\mathrm{S} 1$ & 52 & 50 \\
\hline $\mathrm{S} 2$ & 14 & 13 \\
\hline \multicolumn{3}{|l|}{ Jenis Pekerjaan } \\
\hline Ibu Rumah Tangga & 24 & 23 \\
\hline Wiraswasta & 16 & 15 \\
\hline Karyawan BUMN & 6 & 6 \\
\hline Karyawan Swasta & 59 & 56 \\
\hline \multicolumn{3}{|c|}{ Rata-Rata pengeluaran ( $\mathrm{Rp} / \mathrm{bln})$} \\
\hline$<4.500 .000$ & 23 & 22 \\
\hline $4.500 .000-7.500 .000$ & 38 & 36 \\
\hline$>7.500 .000$ & 44 & 42 \\
\hline
\end{tabular}

Tabel 4. Sebaran perilaku menonton iklan THS

\begin{tabular}{lcc}
\hline Perilaku & $\mathrm{n}$ & $\%$ \\
\hline Channel THS pilihan & 49 & 47 \\
Oshop & 16 & 15 \\
MNC Shop & 39 & 37 \\
Lejel Home Shopping & 1 & 1 \\
DRTV & & \\
Jam Menonton & 5 & 5 \\
06-09 & 2 & 2 \\
09-12 & 9 & 9 \\
12-15 & 11 & 10 \\
15-18 & 4 & 4 \\
18-20 & 74 & 70 \\
Tidak Tentu & & \\
Hari Menonton THS & 5 & 5 \\
Setiap hari & 1 & 1 \\
Hari libur Nasional & 99 & 94 \\
Tidak Tentu & &
\end{tabular}

\section{Alasan Membeli Produk THS}

Alasan yang paling menggerakkan konsumen untuk membeli produk THS yaitu harga sesuai (A6), Hadiah menarik (A7), dan produk unik, berbeda dari pasaran. Prioritas alasan konsumen membeli produk THS dapat ditampilkan pada grafik Thrustone pada Gambar 2.

Beberapa penelitan terdahulu mengenai alasan membeli produk melalui THS, antara lain karena persepsi harga yang lebih murah (Park et al. 2011), hemat waktu, membeli produk dengan informasi yang jelas, mendapatkan produk unik dan inovatif (Chen dan Chen, 2009; Oh \& Jeong, 2015). Hasil penelitian MarkPlus \& Co pada tahun 2003 juga menyebutkan bahwa konsumen di Indonesia terutama wanita bekerja dan ibu rumah tangga sangat memperhatikan informasi harga, model dan spesifikasi produk (Kaihatu et al. 2008).

\section{Pengaruh Iklan terhadap AIDA pada Konsumen yang Sudah Butuh dan Belum Butuh}

Hasil output diagram jalur persamaan struktural pada PLS dengan menggunakan software SmartPLS di sajikan pada Gambar 3. Hasil pengaruh iklan dan hubungan AIDA pada konsumen yang sudah memiliki kebutuhan dan belum memiliki kebutuhan sedikit berbeda. Pada Konsumen sudah butuh, iklan THS sangat berpengaruh terhadap Awareness dan Interest, namun tidak berpengaruh terhadap Desire dan Action. 
Hubungan Awareness - Interest, Desire-Action pada konsumen butuh signifikan. Sedangkan Interest ke Desire tidak signifikan. Pada konsumen belum butuh, Iklan sangat berpengaruh pada Awareness, Desire dan Action. Sedangkan Iklan tidak terlalu memengaruhi

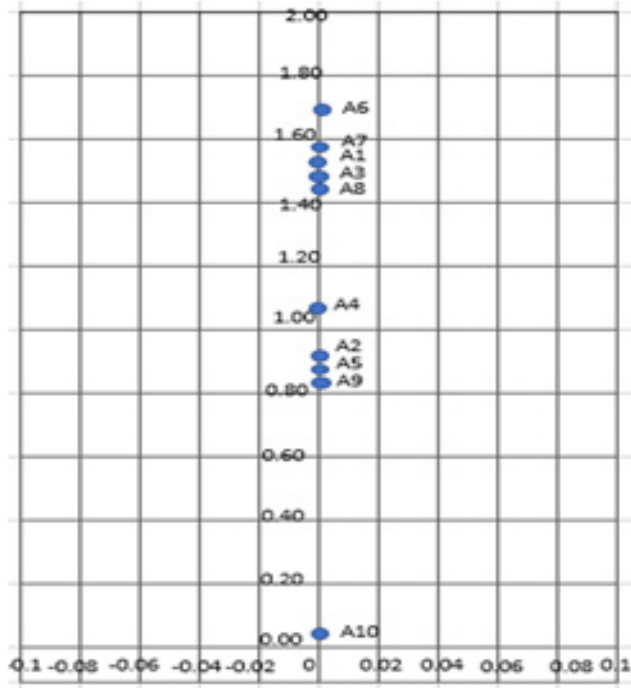

\begin{tabular}{|l|l|}
\hline Kode & Keterangan \\
\hline A1 & $\begin{array}{l}\text { Produk unik/berbeda dari yang ada } \\
\text { dipasarkan }\end{array}$ \\
\hline A2 & Produk sesuai yang dibutuhkan \\
\hline A3 & Produk sedang tren \\
\hline A4 & Produk THS berkualitas \\
\hline A5 & $\begin{array}{l}\text { Harga lebih murah dari produk sejenis } \\
\text { dipasarkan }\end{array}$ \\
\hline A6 & Harga sesuai dengan produk \\
\hline A8 & Hemat waktu, tidak perlu macet \\
\hline A9 & Hemat tenaga, tidak perlu ke toko \\
\hline A10 & $\begin{array}{l}\text { Membeli untuk kesenangan pribadi/untuk } \\
\text { hadiah }\end{array}$ \\
\hline
\end{tabular}

Gambar 2. Hasil prioritas alasan membeli produk THS

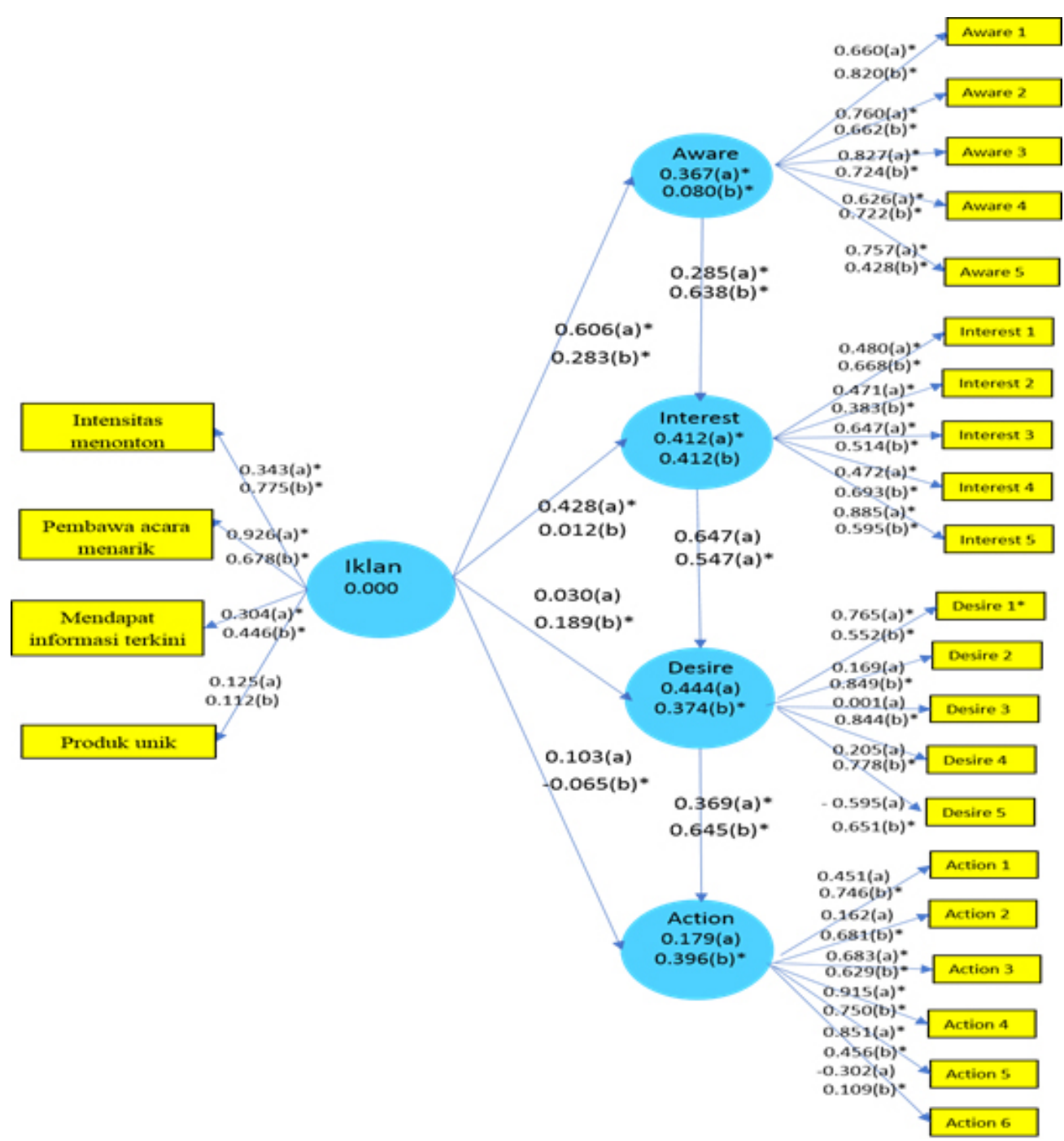

Gambar 3. Hasil output diagram jalur persamaan struktural pengaruh iklan terhadap AIDA
Interest. Hubungan Awareness - Interest, Interest Desire, Desire-Action pada konsumen belum butuh signifikan. Perbandingan $\mathrm{T}$ hitung antara konsumen butuh dan belum butuh selengkapnya pada Tabel 4 . 
Tabel 5. Perbandingan T hitung antara konsumen butuh dan belum butuh

\begin{tabular}{lcccc}
\hline \multicolumn{1}{c}{ Hipotesis } & $\begin{array}{c}\text { T Statistics }(\mid \mathrm{O} / \text { STERR } \mid) \\
\text { Konsumen Butuh }\end{array}$ & Kesimpulan & $\begin{array}{c}\text { T Statistics }(|\mathrm{O} / \mathrm{STERR}|) \\
\text { Konsumen Belum Butuh }\end{array}$ & Kesimpulan \\
\hline Iklan $\rightarrow$ Awareness & $32,5262^{*}$ & Signifikan & $8,643^{*}$ & Signifikan \\
Iklan $\rightarrow$ Interest & $12,9629^{*}$ & Signifikan & 0,369 & Tidak signifikan \\
$\mathrm{Iklan} \rightarrow$ Desire & 0,6098 & Tidak signifikan & 6,643 & Signifikan \\
Iklan $\rightarrow$ Action & 0,9897 & Tidak signifikan & $2,017^{*}$ & Signifikan \\
Awareness $\rightarrow$ Interest & $12,1713^{*}$ & Signifikan & $28,913^{*}$ & Signifikan \\
Interest $\rightarrow$ Desire & 1,0577 & Tidak signifikan & $25,071^{*}$ & Signifikan \\
Desire $\rightarrow$ Action & $2,1461^{*}$ & Signifikan & $29,949^{*}$ & Signifikan \\
\hline
\end{tabular}

\section{Implikasi Manajerial}

Hasil penelitian, didapat memberikan gambaran mengenai profil responden THS. Mengacu pada hasil tersebut, perusahaan THS sebaiknya memiliki strategi produk yang tepat dengan menyeleksi dan mengembangkan produk-produk peralatan masak berkualitas, memiliki nilai tambah, unik, inovatif. Produk memiliki harga jual yang menarik dan kompetitif dengan nilai berkisar antara 1.000.0001.999.999, dengan paket hadiah yang menarik, karena sebagian responden membeli karena tertarik hadiah yang diberikan. Kategori produk selain alat masak yang dapat dikembangkan adalah elektronik rumah tangga. Untuk memudahkan konsumen dalam memiliki produk THS dan meningkatkan kuantitas belanja produk, mekanisme pembayaran cicilan dapat dibuat bervariasi dalam jangka waktu pembayaran, sehingga konsumen merasa ringan untuk membeli produk.

Dengan tidak tentunya jam dan hari menonton konsumen, perusahaan THS harus mampu menempatkan iklan pada waktu yang tepat, melakukan pengulangan jam tayang beberapa kali dalam sehari agar dapat disaksikan oleh banyak konsumen yang dituju. Keterbatasan waktu pada tayangan THS sebaiknya dapat diperluas dengan penyediaan saluran informasi lain seperti website produk sehingga setelah menonton iklan THS, konsumen masih dapat menemukan informasi lanjutan melalui website tersebut.

Hasil pengaruh iklan THS terhadap AIDA memperlihatkan bahwa dampak iklan berbeda-beda tergantung kondisi responden yang menonton. Bila dikaitkan dengan hasil sebelumnya terhadap intensitas, jam dan hari menonton yang tidak tentu, dapat dikatakan sebagian besar responden membeli produk THS tidak terencana. Oleh karena itu, perusahaan THS harus mampu memikirkan cara mengemas iklan dengan baik, menghibur, menampilkan pembawa acara yang menarik, informatif. Hal ini, akan menarik perhatian penonton agar terus memperhatikan program THS yang berlangsung dan tidak berpindah channel selama program.

\section{KESIMPULAN DAN SARAN}

\section{Kesimpulan}

Sebagian besar responden yang berpartisipasi adalah wanita, berusia dewasa, memiliki pendidikan cukup tinggi, bekerja full time dan berkelas menengah atas. Konsumen dalam penelitian ini membeli produk THS tidak terencana atau bukan karena sudah memiliki kebutuhan sebelumnya. Sebagian besar responden menonton iklan THS hanya jika ada waktu saja, tidak tentu dalam jam dan hari menonton.

Dampak iklan berbeda-beda tergantung kondisi awal penonton/pemirsa. Pada konsumen yang sudah butuh, intensitas menonton, informasi dan produk yang unik tidak terlalu berpengaruh. Namun pembawa acara yang menarik berpengaruh terhadap respon konsumen butuh. Pada konsumen yang belum butuh, respon konsumen akan terpengaruh pada intensitas menonton dan pembawa acara, sedangkan informasi terkini dan produk unik, tidak terlalu memengaruhi respon konsumen. Pada konsumen yang sudah memiliki kebutuhan, maka pengaruh iklan pada aspek Awareness dan interest lebih besar, sedangkan Desire dan Action kecil. Pada konsumen yang belum memiliki kebutuhan, aspek Awareness, Desire dan Action lebih besar. Pada responden yang butuh, hubungan A-I dan D-A tinggi. Pada responden yang belum butuh, urutan tahapan A-I, I-D, D-A dilalui sesuai dengan hierarki AIDA. 


\section{Saran}

Penelitian ini memiliki keterbatasan, sehingga diperlukan penyempurnaan baik dibidang kerangka teoritis ataupun dalam penggunaan data contoh, yang dapat digunakan untuk penelitian selanjutnya. Didalam penelitian ini, yang teliti hanya responden yang sudah membeli produk THS, dan tidak diamati respon responden yang belum atau tidak membeli produk. Keterbatasan penelitian ini selanjutnya berada pada tempat pengambilan sampel yang terbatas di area Pekan Raya Jakarta dan hanya beberapa perusahaan THS tertentu yang ada dalam lokasi. Penelitian selanjutnya diharapkan dapat memperluas daerah pengambilan sampel, juga responden yang belum/tidak membeli produk THS sehingga didapatkan karakteristik responden yang lebih bervariasi.

\section{DAFTAR PUSTAKA}

Chen CF, Tsai MH. 2008. perceive value, satisfaction, and loyalty of $\mathrm{tv}$ travel product shopping involvement as a moderator. Tourism Management 29: 1166-1171. https://doi. org/10.1016/j.tourman.2008.02.019.

Chen PC, Chen YJ. 2009. A comparison study of taiwan and us consumer decition-making styles-using TV shopping format. The Journal of International Management Studies 4(1):145-153.

Ha L, Chan SM. 2001. Enhance TV as brand extension: TV viewer's perception and tv commerce on broadcast network's web sites. International Journal on Media Management 3(4):202. https:// doi.org/10.1080/14241270109389969.

Intarto J. 2014. Kreativitas home shopping menggunakan media. http://mediapreneur. wordpress.com. [20 Juni 2015].

Kaihatu TS, Rumambi J, Djati P. 2008. Membidik pasar ibu di Indonesia: sebuah kajian efektivitas pemilihan media beriklan. Universitas
Kristen Petra, Surabaya. http://fportfolio. petra.ac.id/user_files/91-023/JURNAL\%20 -\%20Membidik\%20Pasar\%20Ibu\%20di\%20 Indonesia.pdf [30 Januari 2017].

Lee KK, Jang SN, Kim PJ. 2012. Research on purchase decition factors to TV Home shopping products: digital home appliance. East Asian Journal of Business Management 2(2):13-21.

Lee MS. 2008. Television shopping: the effect of persuasive strategies on parasocial interAction, subjective wellbeing, and impulse buying tendency among older women. Iowa: Iowa State University Digital Repository.

Lin HH. 2010. The effect of TV and online shopping value on online patronage intention in a multichannel retail context. World Academy of Science, Engineering and Technology 4:7-29.

Oh JS, Jeong DY. 2015. The effect of consumers belief about TV home shopping advertising on attitude and purchase intention. Indian Journal of Science and Technology 8(14): 1-7. https:// doi.org/10.17485/ijst/2015/v8i14/68366.

Park H, Lim CM, Bardwaj V, Kim YK, 2011. Benefit segmentation of TV home shoppers. International Journal of Retail \& Distribution Management 39(1):7-24. https://doi. org/10.1108/09590551111104459.

Shaffer TR, Easterling D. 2000. Who is really watching television shopping channels?. http:/www.sbaer. uca.edu/Research/1995/SMA/95swa212.htm. [20 Januari 2017].

Suharjo B. 2005. Sampling Technique - Kuliah Riset Pemasaran. Bogor: Manajemen dan Bisnis, IPB Bogor.

Sumarwan U. 2011. Perilaku Konsumen: Teori dan Penerapannya dalam Pemasaran. Jakarta: Ghalia Indonesia.

Tsai D, Chen W, Chen HK. 2011. Factors influencing irrational buying: the case of television shopping. Asia Pacific Advances in Consumer Research 9: 351-352. 